\title{
'Piracy, the Protection of Vital State Interests and the False Foundations of Universal Jurisdiction in International Law'
}

\author{
MATTHEW GARROD**
}

\section{Introduction}

It is widely asserted by courts and in legal scholarship that, for hundreds of years, universal jurisdiction has applied to the crime of piracy. ${ }^{1}$ While there is no internationally codified definition of universal jurisdiction, the concept, it has been suggested, permits States under international law to prosecute certain crimes that are committed abroad, regardless of any nexus with the offence and in the absence of any link provided by other grounds of prescriptive jurisdiction recognised by international law. ${ }^{2}$ The rationale for this jurisdiction is based upon the supposed 'heinous' nature of the alleged conduct, the perpetrators of which may be prosecuted by every State in order to protect the 'vital interests' or 'fundamental values' of the international community. ${ }^{3}$ Given that universal jurisdiction is supposed to have had as its foundation, and, indeed, its very legitimacy, the suppression of piracy, it is rather surprising that it has not been subject to greater scrutiny. Even commentators who have claimed to study the concept have not examined its alleged origins. ${ }^{4}$

The aim of this article is to challenge the alleged historical legal foundations of universality. By using a range of primary sources, including the treatises of the so-called 'founding fathers' of international law, its central argument is that jurisdiction over 'piracy' is better understood under the protective principle, which arose out of the necessity of maritime powers, roughly between the seventeenth and eighteenth centuries, to protect certain of their vital interests, not least their overseas trade routes and colonial trade and settlements. The protective principle is little understood and has tended to be contested or defined in overlynarrow terms by courts and in legal scholarship. ${ }^{5}$ While a definition of the protective principle has yet to be codified internationally, ${ }^{6}$ the principle permits States under international law to give extraterritorial effect to legislation criminalising conduct abroad that poses a threat to their vital interests, irrespective of any other nexus with the offence. ${ }^{7}$ The article therefore seeks to shed important light on the origins of the protective principle and its contemporary scope of application. 
As will be explained, the rise of the centralised State and the mercantilist system in the sixteenth and seventeenth centuries made the economic strength of the State, through the pursuit of colonial trade, a matter of great importance. The development of jurisdiction was shaped not only by the need to protect trade from pirates, whose conduct amounted to the waging of unlawful warfare and which could not be attributed to any recognised sovereign, but also by the rivalry and war among sovereigns to monopolise the right to navigate the high seas and conduct trade; in seeking to safeguard their trade from each other, claims were also made to uphold the law of nations and supposedly universal values and, indeed, 'humanity' itself. As the disruption of navigation and trade on the high seas was treated as a violation against the law of nations, and every State was permitted to enforce jurisdiction over 'pirates' on the high seas, the maritime powers had the widest possible jurisdiction under international law to protect their vital interests, without having to provide any jurisdictional nexus with the alleged offence.

The article begins by outlining the emergence of the so-called 'golden age of piracy', spanning roughly between $1670-1730 .{ }^{8}$ Thereafter, it examines the threat by piracy to the vital State interests shared by the maritime powers. Part three goes on to explain the development of jurisdiction over piracy under the protective principle, while part four explores the reasons why the suppression of piracy was, nevertheless, often claimed to be for the protection of humanity and in the interest of the law of nations, by examining the theoretical foundations of the protective principle in the works of some of the classical writers on international law. After having examined the development of jurisdiction over piracy in its proper historical context, the article concludes that there is a need to reconceptualise jurisdiction as based on the protection of vital State interests that are shared by the international community.

\section{The Rise of the 'Golden Age of Piracy'}

During the fourteenth and seventeenth centuries, before the development of large public navies, European sovereigns used large numbers of privateers as an instrument for waging war. ${ }^{9}$ Sovereigns issued privateering vessels-that is to say, private armed merchantmen-with licences called 'letters of marque', permitting them to use force in order to capture enemy warships and merchant vessels. ${ }^{10}$ Privateers played a vitally important part in war and were used, in particular, to weaken the economic and military strength of enemy sovereigns. ${ }^{11}$ 
After Spain discovered the West Indies and America in the fifteenth century, it claimed, on the basis of a Papal donation, sovereignty over the high seas and all territories west of an imaginary line off the Azores, in order to exclude potential rival European sovereigns from navigating the high seas and developing trade. ${ }^{12}$ Spain treated as 'pirates' any but Spanish vessels sailing in the West Indies. ${ }^{13}$ Portugal claimed the same to the east of the Azores. ${ }^{14}$ In reaction to the vast wealth realised by Spain, not unsurprisingly, France, England and the Netherlands rejected this claim of sovereignty and waged war against Spain in the West Indies, by licensing privateers to attack its colonial settlements and capture its merchant vessels. ${ }^{15}$ The same reaction occurred in the East Indies against Portugal, not least by the Netherlands, which, as will be shown, provided the broader context for the publication by Grotius of Mare Liberum.

Privateers were used by these sovereigns to force access to colonial trade and to protect their own settlements in the West Indies from being destroyed by Spanish naval forces. While these sovereigns were formally at peace in Europe, there developed a principle of "no peace beyond the line", that is, the imaginary line claimed by Spain dividing Europe from the New World. ${ }^{16}$ Under this principle, there existed 'beyond the line' a de facto war throughout much of the sixteenth and seventeenth centuries. The use of privateers was so effective that, by the close of the seventeenth century, Spain had been forced to negotiate peace treaties. ${ }^{17}$ Accordingly, Spain agreed to formally recognise the territories which each rival sovereign had occupied in the East and West Indies, as well as Africa and America, on the basis that they, in turn, restrained their privateers from attacking Spanish settlements and trade and that the subjects of the respective sovereigns refrained from travelling to, and trading with, each other's colonies.

The signing of these treaties, nevertheless, led to the abandonment of "no peace beyond the line" in favour of a policy of "trade by diplomacy". ${ }^{18}$ It was believed that far greater and stable wealth could be accumulated by the development plantation economies, built upon the back of African slave labour. ${ }^{19}$ This important political and economic development meant that large numbers of privateers employed in the West Indies were no longer needed. On the contrary, it was believed that unless privateers were effectively restrained, they endangered the peaceful relations among sovereigns and the development of trade. The collapse in this formerly reciprocally beneficial relationship led to widespread outbreaks of piracy, as privateers, nevertheless, continued to wage unlawful warfare by attacking without licence not 
only the settlements and trade of Spain, but also that of their former sponsors. ${ }^{20}$ Although the waging of war by European sovereigns competing to develop trade caused the problem of piracy, it was exacerbated by a series of further colonial trade wars, each of which involved the licensing of privateers and, in turn, greater outbreaks of piracy. ${ }^{21}$ Of course, this is not to suggest that other, more widespread, outbreaks of non-'Western' piracy did not occur in other parts of the world, both in earlier and later periods, which had nothing at all to do with European colonialism. ${ }^{22}$

The way in which sovereigns used privateers to wage war for the pursuit of colonial trade raises important considerations as to the relationship between privateers and pirates under international law. Pirates engaged in the exact same conduct as privateers, by using force to attack and capture merchant shipping. ${ }^{23}$ The only difference between them under the developing code of international law in the seventeenth century was that privateers acted under the authority and in the interests of a particular sovereign, and, in return, received that sovereign's protection under the law of war. ${ }^{24}$ Sovereign authorisation legitimised the acts of privateers and made them immune from criminal proceedings by the injured power. ${ }^{25}$ International law developed around the assumption that only sovereigns had the right to wage war, which meant that the resort to force without sovereign authority was considered as an act of hostility and unlawful warfare. ${ }^{26}$ Importantly, the demarcation between privateers and pirates developed as European sovereigns sought to protect their growing economic interests in colonial trade from pirates, on the one hand, and to expand them at the expense of their colonial rivals, through the use of privateers, on the other. ${ }^{27}$ The threat from piracy to the interests of sovereigns is to which this article will now turn.

\section{The Threat by Piracy to Vital State Interests}

The rise of the centralised State and the mercantile system in Europe during the sixteenth and seventeenth centuries made the economic strength of the State a matter of great importance. ${ }^{28}$ It should be noted that the concept of the 'State' in this period was the person of the sovereign, who enjoyed absolute political and economic power over a relatively well-defined territory. ${ }^{29}$ Under mercantilist doctrine, the sovereign's joint objectives were to increase his own wealth and power, relative to that of all others. ${ }^{30}$ To that end, mercantilism placed stress on the development, monopoly and protection by the sovereign of colonial trade. ${ }^{31}$ This was based on the idea that trade produced wealth, which was an essential means to power, 
including prestige, honour and respect; in turn, power was essential for securing the State from external attack, but also for securing access to overseas trade routes and protecting colonial trade. ${ }^{32}$ Unsurprisingly, trade was a major source of competition and war among European sovereigns. One of the ways in which sovereigns pursued colonial trade was through chartered mercantile companies. Private wealthy investors funded these companies, and sovereigns, for a share of their profits, granted them trade monopolies and gave them quasi-sovereign powers, including the right to build forts and even wage war, for example, by licensing privateers. ${ }^{33}$ Sovereigns were also prepared to protect by force the freedom of their companies to navigate the high seas and develop trade "against all and everybody in special who should hinder and damage them", 34 and, indeed, waged war against each other in order to secure the trade of their companies. ${ }^{35}$ The development of economic interests through colonial trade was thus of great importance to the State, and it drove both the emergence and the expansion of European empires. ${ }^{36}$

The importance of trade, and, indeed, the right of sovereigns to wage war in order to pursue and protect it was recognised in the early treatises of modern international law. Molloy suggested that "Trade and Commerce are now become the only Object and Care of all Princes"; ${ }^{37}$ it provided sovereigns with the wealth for "fortifying their Countries with Reputation and Strength". ${ }^{38}$ For Grotius, colonial trade was the sovereign's "sole source of support, renown, and protection". ${ }^{39}$ As will be shown, Grotius's celebrated treatise on Mare Liberum, which formed part of a wider unpublished work, was a defence of the waging of war by the Dutch East India Company against Portugal in the East Indies, in order to gain access to, and eventually monopolise for itself, the lucrative trade in that region. Vattel regarded trade as vital for the State's wealth, strength and security. ${ }^{40}$ These treatises will be returned to below.

Pirates posed a serious threat to the authority and certain vital interests of sovereigns and considered themselves as "free princes", "41 "autonomous sovereigns" "42 and the "Lords of the Sea". ${ }^{43}$ Pirates not only claimed to be sovereigns, but also practiced its prerogatives, by waging war against colonial settlements. Colonial governors in the West Indies and North America reported that their coasts were "infested with pirates" and of being in a "continual state of war". ${ }^{44}$ Piracy was the antithesis of mercantilism; it created insecurity for vital trade routes and threatened to destroy trade across the West Indies and America, Africa and the East Indies. ${ }^{45}$ The governor of Virginia reported that pirates "doth ruin trade ten times worse 
than a war". ${ }^{46}$ The threat to trade is perhaps illustrated no clearer than by the torrent of petitions by colonial governors and merchants to the British Government and the King for an increase in the number and strength of naval warships to protect their trade. ${ }^{47}$ Trade could not leave plantations without convoy by naval warships, which would otherwise be left "at the mercy of the pyrates". ${ }^{48}$ In the Tryals of Eight, the King's Advocate asserted that "English Trade is in the utmost danger at present in America from the prodigious Number of Ships exercised in Piracies" and that it threatened to "put a full stop to our Commerce" ${ }^{49}$ He also asserted that the threat to trade was "Destructive of Government" and "in Violation of the Rights of Nations". ${ }^{50}$ This signifies the importance of trade to the State and denotes that only sovereigns had the right to wage war by disrupting enemy trade. ${ }^{51}$

\section{The Development of Jurisdiction over Piracy under the Protective Principle}

It has been widely suggested by courts and in legal scholarship that piracy was suppressed during the 'golden age' on the basis of universal jurisdiction, and that the rationale for this principle was based upon the supposed 'heinous' nature of the alleged conduct. ${ }^{52}$ This view has been adopted uncritically; it is based on tentative, secondary sources, or else primary sources which have been interpreted wholly out of context. This is illustrated by the following example. Scharf has boldly asserted that "[f]or 500 years, States have exercised [universal] jurisdiction over piratical acts on the high seas". ${ }^{53}$ The only evidence cited by Scharf in support is the work of Randall. Unlike the majority of courts and commentators, who have done little by way of historical research, Randall did cite a single case to support his argument that piracy was subject to universal jurisdiction because it constituted "particularly heinous and wicked acts". 54 However, Randall cited only half of the court's reasoning in that case and misinterpreted jurisdiction. The court in that case did not recognise the existence of universal jurisdiction and declared piracy to be "heinous and wicked" because it was "destructive of all trade and commerce between nation and nations", namely, between England and its colonies. ${ }^{55}$ The court proceeded to assert that it was "the interest of all sovereign Princes" to suppress piracy for the protection of their trade. The King's Advocate in that case also described piracy as "odious and horrid" because it threatened trade in America, which "is no small advantage to the crown of Great Britain", and asserted that "if no stop be put to those depredations, and our trade no better protected, not only Carolina, but all the English plantations in America will be totally ruined in a very short time." 56 Thus, pirates had to be suppressed, according to the King's Advocate, for "the preservation of our 
trade". ${ }^{57}$ There are several other cases in which piracy is declared to be heinous because it threatened trade. ${ }^{58}$ It seems to be the disruption of a sovereign's flag vessels and the threat to trade by persons acting without sovereign authority that pirates were sometimes also called "hostes humani generis" and "beasts of prey". 59 It is important not to place too much weight on the use of these euphemistic labels, none of which were interpreted by courts as permitting universal jurisdiction or given any legal meaning in national laws. ${ }^{60}$

The description of acts of piracy as being 'heinous' has nothing to do with universal jurisdiction; accordingly, it is incapable of providing a theoretical basis for universality. ${ }^{61}$ Given that the disruption of a sovereign's navigation and trade on the high seas was not only a "hostile" act, but also a method of "lawful warfare" when committed by another sovereign's licensed privateers, it should be of little surprise that the same acts, when committed by 'pirates', that is to say, persons acting without a valid licence, were condemned in the strongest terms and called 'enemies'. ${ }^{62}$ The lack of sovereign authority explains the reason why these condemnatory labels were not generally attached to privateers, which engaged in the exact same conduct as pirates. It may even be the case that such labels were used in the endeavour to distinguish pirates from privateers. ${ }^{63}$ As the two practices are distinguishable only in nomine and with regard to State sanction, it is illogical to say that, as a matter of international law, one of them gave rise to universal jurisdiction because it is 'heinous', while the other was lawful and honourable. ${ }^{64}$ It is perhaps for this reason that even some of the most ardent proponents of universal jurisdiction have rejected the 'heinous' rationale. ${ }^{65}$ These and other commentators have either not been able to find any other rationale to support the development of universal jurisdiction over piracy, or have argued instead that universal jurisdiction developed as other 'traditional' grounds of jurisdiction did not cover piracy. ${ }^{66}$ This view is not only simplistic, but it assumes that sovereigns had the willingness and capacity to protect each other's trade, which is unsupported by primary sources. Perhaps more importantly, it does not give sufficient consideration to the development of jurisdiction under the theory of protection, and appears to misinterpret the protection of vital State interests that are shared by the international community, and calls it by a different name, as universal jurisdiction. The idea that grounds of jurisdiction other than universality did not cover piracy seems to be based on a misreading of the work of Grotius, discussed below. ${ }^{67}$

The locus of piracy on the high seas did not inhibit the maritime powers from establishing 
jurisdiction to protect their trade, even "in the most remote parts of the world". ${ }^{68}$ This is illustrated no better than by the municipal law of England governing the trial of pirates during the period under focus. In the final years of the seventeenth century, a report by the King's Advocate abruptly brought to the attention of the English Government that the Vice Admiralty courts in English colonies did not have under the municipal law of England extraterritorial adjudicatory jurisdiction over "offences committed on the high sea". ${ }^{6}$ Moreover, Vice Admiralty courts could not be granted jurisdiction by way of commission to try such offences as English law "doth not extend to the Plantations, and so no Commission can be granted thither upon that law." The report concluded, on the other hand, that "Governors and Vice-Admirals in the Plantations have sufficient power to fit out ships for apprehending of pirates." The law governing the trial of pirates in England was the 'Offences at Sea Act' $1536 .^{70}$ This meant that colonial governors had jurisdiction to capture pirates on the high seas, but any persons taken alive had to be transported to England for trial. The law was regarded as wholly inadequate to protect expanding trade in the East and West Indies. ${ }^{71}$ Accordingly, after war had ended with France, in 1700 Parliament enacted the 'Act for the More Effectual Suppression of Piracy'. ${ }^{72}$ The Preamble to the Act stated that it was intended to protect "Trade and Navigation", particularly in "the East and West Indies, and in Places very remote", from rising numbers of pirates. Section 1 provided that:

all Piracies, Felonies and Robberies committed in or upon the Sea, or in any Haven, River, Creek or Place, where the Admiral or Admirals have Power, Authority or Jurisdiction, may be examined, inquired of, tried, heard and determined, and adjudged, according to the Directions of this Act, in any Place at Sea, or upon the Land, in any of his Majesty's Islands, Plantations, Colonies, Dominions, Forts or Factories ... by the King's Commission ... or any of the Admirals, Vice Admirals, Rear Admirals, Judges or Vice Admiralties, or Commanders of Any of his Majesty's Ships of War [or any other Persons and Officers his Majesty shall think fit to appoint].

From the point of jurisdiction, the legislation is significant. It made provision for the Crown and Admiralty to issue special commissions for the trial in the King's colonies of "Piracies, Felonies and Robberies committed in or upon the Sea". The Act also provided for trials to be conducted on His Majesty's Ships of War in "any Place at Sea". However, this did not mean the high seas. To be sure, in 1720 the King's Advocate issued a legal opinion which stated that "pyrates" captured on the high seas may be tried and executed on His Majesty's Ships of War on the coast of plantations, but there was no precedent "for the tryal of pyrats, to be executed at any place on the high sea at large". ${ }^{73}$ The Act provided for expansive jurisdiction 
for the more effective protection of England's trade, and colonial governors in any part of the world had authority to hold commissions for the trial of pirates whenever their trade needed to be protected. Importantly, there existed no jurisdiction for the trial of pirates other than that provided for under English municipal law. ${ }^{74}$ The Act was not concerned with protecting the trade of foreign sovereigns and left it lawful for England to licence privateers to attack the trade of foreign sovereigns. ${ }^{75}$ Nor did it recognise piracy to be a crime under the law of nations or subject to universal jurisdiction, whereby all sovereigns could exercise their jurisdiction over any and all 'pirates'. This reflected the national laws of the other maritime powers. $^{76}$ The only provision in national laws for the prosecution of crimes against a foreign sovereign were those committed by the prescribing State's subjects, where such persons either acted without or beyond the terms of a privateering licence and attacked the flag vessel of an allied, friendly or neutral sovereign, rather than that of an enemy, or else served under the privateering licences of a foreign sovereign; both circumstances risked causing reprisals and hostilities. ${ }^{77}$

In sum, there is no State practice to support the development of universal jurisdiction over piracy during the 'golden age'. ${ }^{78}$ Rather, jurisdiction developed out of the necessity by States to secure their vital trade routes and protect colonial trade and settlements from unlicensed privateers, whose acts of unlawful warfare could not be attributed to any sovereign. ${ }^{79}$

Notwithstanding the development of protective jurisdiction over piracy, in some pirate trials courts not only described pirates as the "enemy of all mankind" but also claimed that piracy is "a crime against the law of nations", which is suppressed to protect "humanity" and to "preserve Mankind". ${ }^{80}$ In turn, jurisdiction over piracy appears neutral and objective, based on the protection of higher, supposedly 'universal' values. However, this is misleading. The 'pirates' of one sovereign were not the pirates of each and every sovereign everywhere, 81 States also tolerated and even colluded with 'pirates'. 82 British and Spanish colonial governors accused each other to be in "Breach of the Law of Nations" for harbouring 'pirates' who had committed attacks against their own trade. ${ }^{83}$ It is therefore not credible to say that 'pirates' were the enemy of mankind and punished for mankind; rather, pirates were the enemies of the State that labelled persons as such. Nevertheless, it is this rhetoric upon which subsequent courts and commentators have focused and misinterpreted jurisdiction as based upon universality. ${ }^{84}$ In order to better understand why the disruption by pirates of navigation and trade on the high seas was claimed to violate the law of nations, and were 
suppressed in the interest of mankind, it is useful to examine some of the early treatises on international law.

\section{Theoretical Foundations of Protective Jurisdiction under International Law}

One of the most influential writers on modern international law was Hugo Grotius. The most pressing issue for Grotius in the early seventeenth century was the right of the Dutch to freely navigate and conduct trade on the high seas to the East Indies, which was threatened not by 'piracy', but, rather, by Portugal, which had since the late fifteenth century claimed sovereignty over the high seas and all territories in that region in order to monopolise European trade. Complicating matters, Portugal had been ruled by the King of Spain since 1580, and the Dutch Republic had been involved in a war of independence against Spain since 1568, which was treated as a rebellious region of the Spanish empire.

In 1603, the Dutch East India Company captured a Portuguese ship, the Santa Catarina in the Straits of Singapore, which was carrying precious metals at a value of over three million guilders. ${ }^{85}$ Grotius was retained by the Dutch Company in 1604 to write a legal treatise defending the capture and acquisition of the Santa Catarina as lawful prize. The broader legal and political context of Grotius's work was to justify the waging of war by the Dutch Republic against Spain and Portugal in the East Indies, as Grotius put it, in the "zeal for commerce and for enterprise in foreign lands". ${ }^{86}$ Against this contextual backdrop, Grotius prepared a manuscript, "Commentary on the Law of Prize and Booty". ${ }^{87}$ This text was not published until the nineteenth century, but Chapter XII of this work was published separately and anonymously by Grotius at the request of the Dutch Company in 1609, entitled "Freedom of the Seas or the Right which belongs to the Dutch to take part in East Indian Trade" (Mare Liberum). ${ }^{88}$

According to Grotius, "the right to engage in commerce pertains equally to all peoples." Grotius believed that "humanity is united" by trade and that trade is a "necessity" for the "human race". 90 Thus, the prevention of trade is an offence against "nature herself" "must constitute an injury". ${ }^{2}$ In order to justify the Dutch Company, as a private actor, waging war against the subjects of a foreign sovereign, Grotius argued that in a state of nature, such as on the high seas, where judicial recourse is lacking, private individuals and sovereigns share the same powers under the fundamental "precepts" of the law of nature: 
self-defence and the protection of trade. ${ }^{93}$ The prevention of Dutch trade was, moreover, not merely an attack against the Dutch, but an injury to the "human race". ${ }^{94}$ In turn, Grotius could portray the Dutch Company and the Dutch Republic as waging war to open up overseas trade routes and to punish the Portuguese in the interest of the law of nature and for the "benefit of humanity" itself. ${ }^{95}$

Apart from arguing that the freedom of trade is an "incontrovertible right" protected by natural law, Grotius went further by arguing that the law of nations established the following "foundational" rule: "the right to engage in commerce pertains equally to all peoples, and no state or prince has the power to issue a general prohibition forbidding others to enjoy access". 96 Thus, asserted Grotius, "access to all nations is open to all, not merely by the permission of the law of nations but by the command of the law of nations." 97 In order to prevent the Dutch Company from accessing trade routes, Portugal would have to demonstrate that it had established sovereignty, and therefore ownership, over the high seas, which are "immense" and "infinite". 98 There are some things, argued Grotius, which belong to nature and are "impossible" to possess privately, including air, fish and the sea. ${ }^{99}$ Just as Spain and Portugal had claimed sovereignty over the high seas under the authority of Papal decree, which Grotius rejected as the Pope did not have such authority, ${ }^{100}$ Grotius buttressed his argument with higher, binding authority - the law of nations. As the disruption of trade violated the law of nations, sovereigns - and more particularly the Dutch - were permitted to punish foreign nationals and even use military force in a "just war" in order to protect their navigation and trade under the authority and in the interest of the law of nations.

Mare Liberum meant that no sovereign could lawfully claim ownership over vital trade routes on the high seas. ${ }^{101}$ According to Grotius, "if princes possess a right over the sea, it is merely a right of jurisdiction and protection". ${ }^{102}$ This was made clear by Grotius in a subsequent manuscript in defence of Mare Liberum, where Grotius asserted that, as the seas cannot be "occupied" through claims of sovereignty, "[a]ll peoples or their princes in common can punish pirates and others, who commit delicts on the sea against the law of nations."103 Grotius seems to have made a fundamental distinction between the "common" right of sovereigns to punish disruption to their navigation and trade, as violations against the law of nations, and universal jurisdiction. ${ }^{104}$ Nevertheless, in accordance with the thesis in De Jure Praedae, Grotius went on to conclude that "if a prince has real jurisdiction over the sea and indeed the Ocean, this would not have anything to do with his claiming ownership of the sea, 
but with his guarding its community". ${ }^{105}$

Grotius discussed piracy only to the extent of accusing the Portuguese as being 'pirates' for preventing Dutch trade to the Indies, which was "harmful to all mankind" and therefore justified the Dutch in "inflicting punishment on them". ${ }^{106}$ For Grotius, 'piracy' was little more than a label attached by sovereigns to persons that "blockade the high seas and impede the progress of international commerce", which violated the law of nations. ${ }^{107}$ It was thus perfectly just for the Dutch Company to wage war against the Portuguese, as violators of the law of nations, and to punish them by attacking and seizing the Santa Catarina and its cargo.

Grotius later developed his argument in "On the Law of War and Peace", which was published in 1625. In this later work Grotius asserted that:

Kings ... have a Right to exact Punishments [on foreign nationals], not only for Injures committed against themselves, or their Subjects, but likewise, for those which do not particularly concern them, but which are, in any Persons whatsoever, grievous Violations of the Law of Nature or Nations. ${ }^{108}$

Grotius included within this statement the right to punish 'pirates'. Though Grotius did not discuss piracy in any meaningful way, he did suggest that wars are justly waged against pirates as offenders of the law of nature and the law of nations. ${ }^{109}$ While some courts and commentators have interpreted the above, obscure, passage as "the modern theory of universal jurisdiction" over piracy, ${ }^{110}$ others have argued that it is a general theory of universal jurisdiction, not specifically relating to piracy. ${ }^{111}$ However, neither interpretation seems accurate. Rather, the statement has to be set within the context that Grotius first developed his argument in Mare Liberum and the 'universal' right of every sovereign to punish violators of the law of nations, including by labelling such persons as 'pirates', without having to prove "Injuries committed against themselves". Elsewhere, Grotius asserted that sovereigns are "permitted by the Law of Nations" to grant "Commissions to People going to Sea, to attack Pirates wherever they meet them". ${ }^{112}$ The reason that sovereigns granted such commissions was for the protection of their navigation and trade. ${ }^{113}$ It also has to be borne in mind that the right of "Kings" to exact punishment, to which Grotius referred, belonged to European sovereigns, who were able to punish their enemies, not least those in the colonial world, as 'pirates' and violators of the law of nations.

Grotius's argument for Mare Liberum was not made in a legal vacuum, and it is not that 
different to the Spanish theorist of international law, Francisco de Vitoria, who had argued in the previous century for the right of the Spanish sovereign under the law of nations to wage war in self-defence and to punish American Indians for opposing the freedom of Spanish trade. ${ }^{114}$ Writing in the late sixteenth century, Gentili shared the view that Spain had justly waged war against the Indians for refusing to trade with them. ${ }^{115}$ Gentili was the first modern jurist to discuss piracy under the law of nations, although his argument was framed within the context of the law of war and seems to have been implicitly made, at least in part, in response to attacks committed against Spanish colonial trade in the Mediterranean by the so-called 'Barbary' States of North Africa. With this in mind, Gentili argued that sovereigns are permitted under the law of nations to justly wage war against persons who disrupt their navigation and trade on the high seas, and that, where such persons act without sovereign authority, they may be treated as "brigands or pirates". ${ }^{116}$ For Gentili, only sovereigns are entitled to wage war under the law of nations, which means that "pirates and robbers", unlike privateers, "do not come under the law of war" and may be destroyed. ${ }^{117}$ As pirates do not act under the authority of sovereigns in a state of war, Gentili defined pirates simply as "the common enemies of all mankind"; however, what he appears to have really meant is the common enemies of sovereigns, as pirates, according to Gentili, fall outside the law of nations, which is an agreement and compact between sovereigns. ${ }^{118}$ Of course, whether an offender could be treated as a 'pirate' depended upon the recognition of the sovereignty of the licensing authority, which was a political rather than legal decision made by the injured sovereign. Gentili recognised that the high seas are "common to all" sovereigns under the law of nations, ${ }^{119}$ and he argued that it is therefore "right" for all sovereigns to wage war against pirates, because "piracy is contrary to the law of nations" and a "violation of the common law of humanity and a wrong done to mankind". ${ }^{120}$ It seems to have been the disruption of a sovereign's navigation and trade on the high seas by unlicensed privateers in time of peace which Gentili considered to violate the law of nations, rather than 'piracy' per se. Gentili was not detailing the practice of sovereigns at that time, but instead prescribing that sovereigns 'should' wage war against pirates. This was an argument attractive to sovereigns for the protection of their navigation and trade; it was also favourable to the Spanish Crown, for whom Gentili subsequently worked as an advocate, which was at war with the Dutch Republic as well as the Barbary States and treated their privateers as 'pirates'. Thus, in similar terms to the argument made by Grotius, sovereigns are permitted by the law of nations to wage war against their enemies as 'pirates' and enforce jurisdiction over them on the high seas as violators of the law of nations, in order to secure vital trade routes and 
protect trade. What is more, this could be done in the interest of 'humanity'.

Grotius was a major influence on Emer de Vattel, writing on the "Law of Nations" in the mid-eighteenth century. ${ }^{121}$ Vattel described the law of nations as the law of nature applied to the relations of independent sovereigns living in a state of nature. ${ }^{122}$ Vattel made the general proposition that the law of nations is "of such importance to the safety of all states" that all nations have the right to use "forcible means" for the purpose of repressing any nation that tramples it "under foot". ${ }^{123}$ Writing more specifically on "the Sea", a nation that violates the law of nations by claiming sovereignty over the high seas, suggested Vattel, "does an injury to all nations; it infringes their common right". ${ }^{24}$ Although it is not discussed in detail by Vattel, the "common right", to which he referred, includes the right of navigation and trade, particularly given that Vattel makes reference to Grotius's Mare Liberum and the "exceeding importance" of trade to the wealth, strength and security of the State. ${ }^{125}$ The "common enemy" claiming sovereignty over the seas may, moreover, be punished by injured States, including by the use of military force, in the interest of the law of nations and to "discharge their duty" to "human society". ${ }^{126}$ As Vattel put it: "Nations have the greatest interest in causing the law of nations, which is the basis of their tranquillity, to be universally respected." 127

It is within this context that Vattel's passage on piracy has to be understood:

although the justice of each nation ought in general to be confined to the punishment of crimes committed in its own territories, we ought to except from this rule those villains, who, by the nature and habitual frequency of their crimes, violate all public security, and declare themselves the enemies of the human race. Poisoners, assassins, and incendiaries by profession, may be exterminated wherever they are seized; for they attack and injure all nations, by trampling under foot the foundations of their common safety. Thus pirates are sent to the gibbet by the first into whose hands they fall. ${ }^{128}$

This passage gives the impression that 'pirates' are punished by every State on behalf of all nations, and, unsurprisingly, has been cited in support of universal jurisdiction. ${ }^{129}$ On closer inspection, the theory of Vattel has nothing to do with universality and is no different from that of Grotius. Indeed, 'pirates' are, for Vattel, persons that violate the law of nations, by disrupting the freedom of navigation and trade on the high seas. The description by Vattel of 'pirates' as the "enemies of the human race" appears little different from Vattel's description of a State claiming sovereignty over the high seas as a "common enemy". As the law of 
nations, in Vattel's view, provides States with the "foundations of their common safety", all States are permitted, as an exception to the territoriality of jurisdiction, to punish 'pirates', to protect their "common right" of navigation and trade and "defence and safety"; ${ }^{130}$ what is more, this could be done in the interest of enforcing the law of nations and for the benefit of all nations. Given that Vattel treated the law of nations as the law of nature applied to sovereigns and, as did Grotius, viewed trade as beneficial to the "human race"," ${ }^{131}$ and therefore suggested that States are under a general obligation to protect and foster trade, ${ }^{132}$ presumably 'pirates', by disrupting navigation and trade, could also be punished for the benefit of humanity. ${ }^{133}$

At the heart of these early treatises on international law is the theory of protection, which reconciled the protection of navigation and trade with the law of nations and supposedly universal principles and, indeed, humanity itself. As navigation and trade were protected by the law of nations, no State could claim sovereignty over the high seas and all States were permitted, under the authority and in the interest of the law of nations, to enforce jurisdiction on the high seas, and even use military force, to secure their vital trade routes and protect trade from violators of the law of nations. It is within this intellectual framework that the maritime powers legitimised the protection of their navigation and trade, both from each other and 'pirates', during the 'golden age' and beyond.

\section{Concluding Remarks}

This article has challenged the common understanding that universal jurisdiction emerged out of the suppression of piracy and suggested that jurisdiction instead represents one of the earliest and most important developments of the protective principle, the origins of which have rarely been examined and are little understood. As the disruption of navigation and trade on the high seas was treated by States as a violation against the law of nations and harmful to humanity, in order to safeguard their trade from each other during disputes and rivalry, claims were also made to suppress 'pirates' in the interest of the law of nations and for the benefit of humanity. Importantly, as all States were permitted to enforce jurisdiction on the high seas over pirates, given that the high seas could not be owned by any one particular sovereign and that pirates were deemed to fall outside the protection of any sovereign power, it was therefore unnecessary, as a matter of international law, to justify the prescription of national laws extraterritorially by providing a nexus with an offence under a particular ground of 
jurisdiction. ${ }^{134}$ The upshot of all of this is that each of the maritime powers possessed, in time of peace, the widest possible jurisdiction under international law for the protection of their vital interests on the high seas, without having to prove any nexus with alleged pirates; at the same time, the restriction of jurisdiction to 'piracy' protected from interference by each other their own sovereign rights of navigation and trade. It should be noted that this broad right of protective jurisdiction over piracy, which does not require a jurisdictional nexus between a prescribing State and an alleged offence, was eventually codified in the 1982 UN Convention for the Law of the Sea. ${ }^{135}$

There is a need, it is submitted, to reconceptualise jurisdiction over piracy as based on the protection of vital State interests that are shared by the international community, which has been widely misinterpreted by courts and in legal scholarship, and called by a different name, as universal jurisdiction. This is due, in large part, to the persistent reliance upon secondary, tentative sources, or the citation of primary sources, wholly out of context. Consequently, universal jurisdiction is based on false foundations and has been allowed to develop as a hollow concept. The implications are twofold. First of all, it raises serious doubts, as a matter of international law, as to the validity and legal basis of universality over piracy, the use of which has been invoked in recent years by maritime powers seeking to protect their vital trade routes and flag vessels off the coast of Somalia and, to that end, has been affirmed by the UN Security Council. ${ }^{136}$ Second, universal jurisdiction should not be expanded to encompass crimes under international law by analogising them with piracy. ${ }^{137}$ For the reason that jurisdiction has traditionally developed over piracy on the high seas under the protective principle, the attempts made by a handful of States in recent years to exercise universality over crimes other than piracy, allegedly committed in the territory of other States, has given rise to inter-State disputes and led to the concept's validity and scope being the subject of heated debate before the UN General Assembly. ${ }^{138}$

\footnotetext{
${ }^{*}$ Senior Lecturer in Law, School of Law, University of Portsmouth.

* This is an Accepted Manuscript of an article published by Taylor \& Francis in Diplomacy \& Statecraft on 22 May 2014, available online: http://www.tandfonline.com/10.1080/09592296.2014.907060

${ }^{1}$ See S.S. Lotus, Judgment No 9, 1927, PCIJ, Series A, No. 10, per Judge Moore (Dis. Op.), pp. 70-71; Arrest Warrant of 11 April 2000 (Congo v Belgium) (14 February 2002), per Judges Higgins et al. (J. Sep. Op.), pp. 79, 81; E.D. Dickinson, "Is the Crime of Piracy Obsolete?", Harvard Law Review, 38(1925), pp. 336-389, 351; M. Akehurst, "Jurisdiction in International Law", British Yearbook of International Law, 46(1972-1973), p. 160; D.W. Bowett, "Jurisdiction: Changing Patterns of Authority over Activities and Resources", British Yearbook of International Law, 53(1982), p. 11; G. Abi-Saab, "The Proper Role of Universal Jurisdiction", Journal of International Criminal Justice, 1(2003), pp. 599-600; S. Macedo (ed.), The Princeton Principles on Universal Jurisdiction (New Jersey, 2001), p. 45; V. Lowe, Jurisdiction, in M.D. Evans (ed.), International Law (Oxford,
} 
2003), p. 343; J.A. Fernández, Hostis Humani Generis: Pirates, Slavers, and Other Criminals, in B. Fassbender \& A. Peters (eds.), The Oxford Handbook of The History of International Law (Oxford, 2012), Chap. 5.

2 Council of Europe, AU-EU Technical Ad Hoc Expert Group, "Report on the Principle of Universal Jurisdiction", Final Report, 16 April 2009, Doc. 8672/1/09 REV 1, § 8; Institute of International Law, "Universal criminal jurisdiction with regard to the crime of genocide, crimes against humanity and war crimes", Resolution adopted in Krakow, 2005, §1.

${ }^{3}$ Arrest Warrant, per Judges Higgins et al. (J. Sep. Op.), pp. 78, 81; per Judge Van den Wyngaert (Dis. Op.), ibid, p. 166; U.S. v Yunis, 681 F.Supp. 896 (1988); Macedo, p. 48; J.P. Grant \& J.C. Barker, Parry and Grant Encyclopaedic Dictionary of International Law (Oxford, 2009), p. 645.

4 L. Reydams, Universal Jurisdiction: International and Municipal Perspectives (Oxford, 2003); E. Kontorovich, "Universal Jurisdiction and the Piracy Analogy", Harvard International Law Journal 45(2004); R. O'Keefe, "Universal Jurisdiction: Clarifying the Basic Concept", Journal of International Criminal Justice, 2(2004); S. Yee, "Universal Jurisdiction: Concept, Logic, and Reality", Chinese Journal of International Law, 10(2011).

${ }^{5}$ Arrest Warrant, per Judge Guillaume (Sep. Op.), p. 42; American Law Institute, "Restatement of the Law, Third, Foreign Relations Law of the United States", (1987), § 402; AU-EU Expert Group, § 12; Reydams, p. 5; Kontorovich, "Piracy Analogy", pp. 189-190; E. Kontorovich, "The Inefficiency of Universal Jurisdiction", University of Illinois Law Review, 1(2008), p. 394; B, Simma \& A.T, Müller, Exercise and Limits of Jurisdiction, in J. Crawford \& M. Koskenniemi (eds.), The Cambridge Companion to International Law (Cambridge, 2012), p. 143.

${ }^{6}$ Report of the United Nations (UN) International Law Commission on the work of its fifty-eighth session, 1 May - 9 June and 3 July - 11 August 2006, UN Doc. A/61/10, Annex E.

${ }^{7}$ I. Cameron, The Protective Principle of International Criminal Jurisdiction (Aldershot, 1994); C.L. Blakesley, Extraterritorial Jurisdiction, in M.C. Bassiouni (ed.), International Criminal Law, II, Multilateral and Bilateral Enforcement Mechanisms (The Netherlands, 2008), pp. 108-109; Research on International Law Under the Auspices of the Harvard Law School, Part II, "Jurisdiction with Respect to Crime", American Journal of International Law (Supp.), 29(1935), p. 543.

${ }^{8}$ J.H. Baer (ed.), British Piracy in the Golden Age: History and Interpretation, 1660-1730, vol. I (London, 2007), p. x.

${ }^{9} \mathrm{I}$ am grateful to the anonymous reviewer for bringing to my attention the use of privateers in the conflict between the Duchy of Mecklenburg and Kingdom of Denmark for the Swedish Crown between 1373 and 1394. See also L.J. Sechrest, "Privateering and National Defence: Naval Warfare for Private Profit", Independent Institute, Working Paper No.41(2001), pp. 5-8.

${ }^{10}$ Serchest, ibid; D.J. Starkey, British Privateering Enterprise in the Eighteenth Century (Exeter, 1990), pp. 3536; Fernández, p. 123.

11 J.A. Wombwell, The Long War Against Piracy: Historical Trends (Kansas, 2010), p. 10; Kontorovich, "Piracy Analogy", pp. 210-212; J.W. Bingham, "Research in International Law IV: Piracy (Draft Convention Prepared for the Codification of International Law)", American Journal of International Law (Supp.), 26(1932), p. 803; E.W. Hall, A Treatise on International Law (Oxford, 1890), pp. 462-463; "Belligerent Rights at Sea", 14 November 1927, CAB (Cabinet Papers, The National Archives, Kew, United Kingdom) 24/189/36.

${ }^{12}$ See J. Muldoon, Who Owns the Sea, in B. Klein (ed.), Fictions of the Sea: Critical Perspectives on the Ocean in British Literature and Culture (Aldershot, 2002).

${ }^{13}$ M. Rediker, Villains of all Nations: Atlantic Pirates in the Golden Age (London, 2004), pp. 21-22; J.E. Thompson, Mercenaries, Pirates, \& Sovereigns (Chichester, 1994), p. 116.

${ }_{14}^{14}$ Muldoon; Treaty between Spain and Portugal concluded at Tordesillas, 7 June 1494.

${ }^{15}$ V. Barbour, "Privateers and Pirates in the West Indies", The American Historical Review, 16(1911). V.W. Lunsford, Piracy and Privateering in the Golden Age Netherlands (Basingstoke, 2005), p. 9.

${ }^{16}$ P. Earle, The Pirate Wars (London, 2003), p. 96; W.G. Grewe \& M. Byers (Tr.), Epochs of International Law (Berlin, 2000), pp. 152-162.

${ }^{17}$ Treaty of Münster 1648, Articles V,VI, LXXV; Treaty of Madrid 1670.

${ }^{18}$ Baer, p. xiii.

${ }^{19}$ J. Black, A Brief History of Slavery. A New Global History (London, 2011), Chap. 3.

${ }^{20}$ Baer, p. xiii; Wombwell, pp. 10, 12; Rediker, Chap. 2; Thompson, Chap. 3; Fernández, p. 123; R.C. Ritchie, Government Measures against Piracy and Privateering in the Atlantic Area, 1750-1780, in D.J. Starkey \& E.E. Heslinga \& J. Moore (eds.), Pirates and Privateers. New Perspectives on the War on Trade in the Eighteenth and Nineteenth Centuries (Exeter, 1997), Chap. 1.

${ }^{21}$ War of the League of Augsburg (1689-1696); War of the Spanish Succession (1701-1713); War of Quadruple Alliance (1718-1720).

${ }^{22}$ See J.K. Kung \& C. Ma, “Trade or Raid? Voyages of Discovery, Trade Autarky, and the 'Merchant' Pirates 
of Imperial China" (2011): www.ihome.ust.hk/ sojk/Kung_files/Piracy_China.PDF.

${ }^{23}$ Hall, p. 254.

${ }^{24}$ C. Greenwood, "War, Terrorism, and International Law", Current Legal Problems, 56(2003), p. 512; D.A. Azuni, The Maritime Law of Europe, vol. II (New York, 1806), pp. 351-355; Kontorovich, "Piracy Analogy", pp. 217, 219;

Starkey, p. 19.

25 "First, Second and Third Interim Reports from the Committee of Enquiry into Breaches of the Laws of War, with Appendices", 26 February 1920, CAB24/111, pp. 19, 48.

${ }^{26}$ Greenwood; United States v Brig Malek Adhel, 43 U.S. 210 (1844), p. 232.

${ }^{27}$ Starkey, p. 19.

${ }^{28}$ K. Zemanek, "Was Hugo Grotius Really in Favour of the Freedom of the Seas?", Journal of the History of International Law, 1(1999), p. 52.

${ }^{29}$ S. Beaulac, "The Westphalian Legal Orthodoxy - Myth or Reality?", Journal of the History of International Law, 2(2000).

${ }^{30}$ Viner, "Power Versus Plenty as Objectives of Foreign Policy in the Seventeenth and Eighteenth Centuries", World Politics, 1(1948).

${ }^{31}$ F.C. Palm, "Mercantilism as a Factor in Richelieu's Policy of National Interests", Political Science Quarterly, 39(1924); M.E. Mata, "From Pioneering Mercantile State to Ordinary Fiscal State: Portugal $16^{\text {th }}-19^{\text {th }}$ Centuries", Journal of Iberian and Latin American Economic History, 25(2007); Lunsford, p. 179.

${ }^{32}$ Viner, p. 10.

${ }^{33}$ C. Molloy, De Jure Maritimo Et Navali: or, A Treatise of Affairs Maritime and Commerce (London, 1690), BK III, p. 415; C.H. Alexandrowicz, An Introduction to the History of the Law of Nations in the East Indies (London, 1967), pp. 15, 27; T.L. Knusten, A History of International Relations Theory (Manchester, 1997), pp. 89-90; Black, Slavery, p. 83; Lunsford, pp. 10, 20; Rediker, p. 22; Thomson, p. 33; Warrant for William Ussling to Establish a General Company for Trade to Asia, Africa, America and Magellanica, 21 December 1624, Article XXIX: www.avalon.law.yale.edu/17th_century/charter_012.asp; Charter of the Dutch West India Company, 3 June 1621: www.avalon.law.yale.edu/17th_century/westind.asp; Lunsford, pp. 60-61, 107, 179; M. Koskenniemi, "International Law and the Emergence of Mercantile Capitalism: Grotius to Smith", (unpublished paper), pp. 19-20: www.helsinki.fi/eci/.

${ }^{34}$ Warrant for William Ussling, Articles XXV \& XXVI.

${ }^{35}$ A. Wiendl, "The Asiento de Negros and International Law", Journal of the History of International Law, 10(2008), p. 242.

${ }^{36}$ R.J. Evans, "The Rise and Fall of European Empires from the 16th to the 20th Century", Gresham College Lecture Series (2011-2012): www.gresham.ac.uk/professors-and-speakers/professor-richard-j-evans-fba.

${ }^{37}$ Molloy, BK I, pp. ix, x-xi.

${ }^{38}$ Ibid, p. 72; ibid, BK III, pp. 413, 416.

${ }^{39}$ H. Grotius, Commentary on the Law of Prize and Booty (M.J. Van Ittersum (ed.), Indianapolis, 2006), Chap. $\mathrm{XV}, \mathrm{p} .465$.

${ }^{40}$ E. Vattel, The Law of Nations, Or, Principles of the Law of Nature, Applied to the Conduct and Affairs of Nations and Sovereigns, with Three Early Essays on the Origin and Nature of Natural Law and on Luxury (B. Kapossy \& R. Whitmore (eds.), Indianapolis, 2008).

${ }^{41}$ Calendar of State Papers, Colonial Series, America and West Indies, vol. 5, p. 1124 (hereafter CSPCSAWI).

${ }^{42}$ P. Bobbitt, Terror and Consent (London, 2008), p. 32.

4320 October 1721 ADM (Admiralty Records, National Archives, Kew, United Kingdom), 1/1598/12.

${ }^{44}$ CSPCSAWI, vol. 18 , p. $29 ;$ ibid, p. 445.

${ }^{45}$ Rex v Dawson (1696), 13 How. St. Tr. 451, p. 453; Trial of Captain William Kidd, at the Old Bailey, for Murder and Piracy upon the High Seas; and of Nicholas Churchill, James Hove, Robert Lamley, William Jenkins, Gabriel Loff, Hugh Parrot, Richard Barlicorn, Abel Owens, and Darby Mullins, for Piracy: 13 William III. A.D. 1701, 14 How. St. Tr. 123, pp. 152-154, 216; D. Defoe, A General History of the Pyrates (1724) (M. Schohorn (ed.), London, 1972), p. 26; Rediker, Chap. 2; P. Linebaugh \& M. Rediker, The Many-Headed Hydra. Sailors, Slaves, Commoners, and the Hidden History of the Revolutionary Atlantic (Boston, 1992), p. 144; J.L. Anderson, Piracy and World History, in C.R. Pennell (ed.), Bandits at Sea. A Pirates Reader (London, 2001), p. 95; P.T. Leeson, "An-arrgh-chy: The Law and Economics of Pirate Organisation", Journal of Political Economy, 115(2007), p. 1053; A. Bialuschewski, "Black People under the Black Flag: Piracy and the Slave Trade on the West Coast of Africa, 1718-1723", Slavery and Abolition, 29(2008), pp 465-466; Lunsford, pp. 103, 106-107.

${ }^{46}$ CSPCSAWI, vol. 18 , p. 500.

${ }^{47}$ Ibid, vol. 16, pp. 235, 404; ibid, vol. 17, pp. 72, 769, 877, 905; ibid, vol. 29, pp. 54, 411, 587i, 596, 661; ibid, vol. 30, pp. 10, 737, 797; ibid, vol. 32, p. 251; R.G. Marsden (ed.), Documents Relating to Law and Custom of 
the Sea (London, 1915), vol. II, p. 179.

${ }^{48}$ CSPCSAWI, vol. 18, p. 395; ibid, vol. 29, p. 595; ibid, vol. 30, p. 54.

${ }^{49}$ Tryals of Eight Persons Indicted for Piracy \&c., held in Boston within His Majesty's province of the Massachusetts-Bay in New-England, on the 18th of October (1717), p. 13.

${ }^{50} \mathrm{Ibid}$, p. 7.

${ }^{51}$ See also The Trial of Major Stede Bonnet, and Thirty-three others, at the Court of Vice Admiralty, at Charles Town, in South Carolina, for Piracy: 5 George I. A.D. 1718, 15 How. St. Tr. 1231 (1718), per King's Advocate, p. 1243; per Judge Trott, ibid, p. 1235.

${ }_{52}$ See notes $1 \& 3$.

${ }^{53}$ M.P. Scharf, "Application of Treaty-Based Universal Jurisdiction to Nationals of Non-Party States", New England Law Review, 35(2000-2001), p. 369. See also M.P. Scharf, "Jurisdiction with Respect to Crime: Universal Jurisdiction and the Harvard Research", in J.P. Grant and J. Craig Barker, eds., Harvard Research in International Law: Contemporary Analysis and Appraisal (Buffalo, 2007).

${ }^{54}$ K. Randall, "Universal Jurisdiction", Texas Law Review, 66(1987-1988), p. 794.

${ }^{55}$ Trial of Bonnet, per Judge Trott, p. 1235. See also Rex v Dawson, per King's Advocate, p. 482; Trial of Kidd, pp. 171-173.

${ }_{57}^{56}$ Ibid, p. 1243.

${ }^{57}$ Ibid, p. 1244.

${ }^{58}$ Tryals of Eight, per King's Advocate, pp. 6-7; Rex v Dawson, per Sir Charles Hedges, p. 454; Proceedings of the Court held on the Coast of Africa upon Trying of 100 Pirates taken by his Maljes]ties Ship Swallow (1722), HCA (Records of the High Court of Admiralty, The National Archives, Kew, United Kingdom), 1/99; Lunsford, p. 35 .

59 Trial of Bonnet, per Judge Trott, p. 1235; per King's Advocate, ibid, p. 1243; Trial of Kidd, per King's Advocate, pp. 154, 212; Tryals of Eight, per King's Advocate, p. 6. See also Spanish Ordinance of the Royal Navy of 1748, Article 109; United States v Brig Malek Adhel, p. 232; Lunsford, p. 55.

${ }^{60}$ See the compendium of national laws on piracy collated by the Preparatory Work of the Harvard Research, S. Morrison (ed.), "A Collection of Piracy Laws of Various Countries", American Journal of International Law (Supp.), 26(1932), pp. 887-1013.

${ }^{61}$ Kontorovich, "Piracy Analogy", pp. 233-235; United States v The Ambrose Light, 25 F 408 (S.D.N.Y. 1885), p. 423.

${ }^{62}$ United States v Brig Malek Adhel, p. 232.

${ }^{63}$ Lunsford, p. 35.

${ }^{64}$ See also D. Gould, Cicero's Ghost. Rethinking the Social Construction of Piracy, in M.J. Struett \& J.D. Carlson \& M.T. Nance, Maritime Piracy and the Construction of Global Governance (New York, 2013), p. 34.

${ }^{65}$ C. Kreb, "Universal Jurisdiction over International Crimes and the Instiut de Droit International", Journal of International Criminal Justice, 4(2006), p. 569; Kontorovich, "Piracy Analogy".

${ }^{66}$ I. Brownlie, Principles of Public International Law (Oxford, 1998), p. 308; M.C. Bassiouni, "Universal Jurisdiction for International Crimes: Historical Perspectives and Contemporary Practice", Virginia Journal of International Law, 42(2001-2002), pp. 89, 96; S. Villalpando, "The Legal Dimensions of the International Community", European Journal of International Law, 21(2010), p. 406; Abi-Saab; AU-EU Expert Group, p. 2; Scharf; Randall, p. 792; Yee, p. 506; A. Middelburg, Piracy in Legal Context: Prosecution of Pirates Operating off the Somali Coast (The Netherlands, 2011), pp. 29-30.

${ }^{67}$ See Fernández, pp. 121, 129-130; Middelburg, ibid.

${ }^{68}$ See Rex v Dawson, per Sir Charles Hedges, p. 455; Trial of Bonnet, per Judge Trott, p. 1234; Trial of Quelch, 14 How. St. Tr. 1067 (1704); The Trials of Five Persons for Piracy, Felony and Robbery... Held at the CourtHouse in Boston ... the Fourth Day of October, Anno Domini, 1726.

${ }^{69}$ CSPCSAWI, vol. 11, p. 1578.

${ }^{70} 28$ Hen. VIII, c. 15.

${ }^{71}$ CSPCSAWI, vol. 17, pp. 495, 749 .

72 (1700) 11 \& 12 William III, c. 7.

${ }^{73}$ Marsden, vol. II, pp. 252-255.

${ }_{75}^{74}$ CSPCSAWI, vol. 31, p. 88.

${ }^{75}$ Section 8.

${ }^{76}$ Morrison.

${ }^{77}$ Rex v Dawson, per King's Advocate, p. 453; per Sir Charles Hedges, ibid, p. 455; Trial of Kidd, per King's Advocate, pp. 152-154, 216; Trial of Quelch, per Queen's Advocate, p. 1084; French Ordinance of 1681, Article 3; Spanish Ordinance of 1801, Article 29; Lunsford, Chap. 2.

${ }^{78}$ Rubin; Bingham, p. 761.

${ }^{79}$ See also Trial of Bonnet, per King's Advocate, p. 1243; Tryals of Eight; CSPCSAWI, vol. 29, pp. 64, 489, 
518; 587i, 596; ibid, vol. 30, pp. 688, 742, 800; ibid, vol. 32, p. 65; HCA 1/99; Tryals of Thirty-Six Persons Indicted for Piracy, Twenty Eight of them upon full Evidence were found Guilty, and the Rest Acquitted, 12 June \& 25 November 1723, 25 May 1724, ADM1/2452/4; J. Black, Britain as a military power 1688 - 1815 (London, 1999), p. 42; J. Black, Crisis of Empire. Britain and American in the Eighteenth Century (London, 2010), p. 38.

${ }^{80}$ See Tryals of Eight, pp. 2, 6; Trial of Quelch, per Attorney General and Her Majesty's Advocate; The Trial of Captain Thomas Green, and his Crew, at the High Court of Admiralty of Scotland, for Piracy: 4 Anne A.D. 1705, pp. 1224, 1272; Trial of Bonnet, per King's Advocate, p. 1243; Trial of Kidd, pp. 152-154, 171-173; Molloy, BK I, p. viii.

${ }^{81}$ See also Fernández, p. 124.

${ }^{82}$ Lunsford, p. 167; P.B. Nutting, "The Madagascar Connection: Parliament and Piracy, 1690-1701", The American Journal of Legal History, 22(1978), pp. 205-215.

${ }^{83}$ Defoe, pp. 45-48.

${ }^{84}$ See Lotus, per Judge Altamira (Dis. Op.), p. 95; per Judge Moore (Dis. Op.), ibid, pp. 70-71; Arrest Warrant, per Judges Higgins et al. (J. Sep. Op.), p. 85; The Republic of Seychelles v Houssein Mohammed Osman and ten Others, Criminal Side No. 19 of 2011, § 32; AU-EU Expert Group, p. 2; H.E.J.L. Jesus, "Protection of Foreign Ships against Piracy and Terrorism at Sea: Legal Aspects", International Journals of Marine \& Coastal Law, 18(2003), p. 374.

${ }^{85}$ Grotius, Commentary, p. xiii.

${ }^{86} \mathrm{Ibid}$, Chap. XII. See also M.J. Van Ittersum, "Dating the manuscript of De Jure Praedae (1604-1608): What watermarks, foliation and quire divisions can tell us about Hugo Grotius' development as a natural rights and natural law theorist”, History of European Ideas, 35(2009), pp. 125-126.

${ }^{87}$ Grotius, Commentary.

${ }^{88}$ H. Grotius, The Free Sea (D. Armitage (ed.), R. Hakluyt (tr.), Indianapolis, 2004).

${ }^{89}$ Grotius, Commentary, Chap. XII, pp. 303-304.

${ }^{90}$ Ibid.

${ }^{91}$ Ibid.

${ }^{92}$ Ibid, p. 365.

${ }^{93}$ Ibid, Chap. II, p. 23; ibid, Chap. XII, p. 365.

${ }^{94}$ Ibid, Chap. XII, p. 361.

${ }^{95}$ Ibid, pp. 303-304; Grotius, The Free Sea, p. 58. See also Koskenniemi, pp. 7-8.

${ }^{96}$ Grotius, Commentary, Chap. XII; Grotius, The Free Sea, p. 10.

${ }^{97}$ Grotius, Commentary, ibid, p. 300.

${ }^{98}$ Ibid.

${ }^{99}$ Ibid, p. 331.

${ }^{100}$ Ibid.

${ }_{101}^{1}$ Ibid, p. 274.

102 Ibid, p. 339.

${ }^{103}$ H. Grotius, Hugo Grotius's Reply: Defense of Chapter $V$ of the Mare Liberum Which had been attacked by William Welwod, Professor of Civil Law, in Chapter XXVII of that book written in English to which he gave the title An Abridgement of All Sea-Lawes, in Grotius, The Free Sea, p. 185.

${ }^{104}$ See also Bassiouni, p. 109.

${ }^{105}$ Grotius, Hugo Grotius's Reply, p. 185.

${ }^{106}$ Grotius, Commentary, Chap. XIV, pp. 368-369.

${ }^{107} \mathrm{Ibid}$; Grotius, Hugo Grotius's Reply, p. 185.

${ }^{108}$ H. Grotius, De Jure Belli Ac Pacis (1625) (R. Tuck \& J. Barbeyrac (eds.), Indianapolis, 2005), BK II, Chap. XX, § XL. 1.

${ }^{109}$ Ibid, § XL. 3.

${ }^{110}$ See Bassiouni, p. 99; W.B. Cowles, "Universality of Jurisdiction over War Crimes", California Law Review, 33(1945), pp. 190, 204; P. Campbell, A Modern History of the International Legal Definition of Piracy, in B.A. Elleman \& A. Forbes \& D. Rosenberg, Piracy and Maritime Crime. Historical and Modern Case Studies (Newport, 2010), pp. 20-21; The Republic of Seychelles v Mohamed Ahmed Ise and Four Others, Criminal Side No. 75 of 2010, § 22 .

${ }^{111}$ P. Haggenmacher, "Sur un passage obscur de Grotius", The Legal History Review, 51(1983), p. 295.

${ }^{112}$ Grotius, De Jure Belli, BK II, Chap. XX, § XIV.

${ }^{113}$ See Marsden, vol. I, p. 385; ibid, vol. II, pp. 105, 112.

${ }^{114}$ R. Tuck, The Rights of War and Peace (Oxford, 1999), Chap. 2.

115 A. Gentili, De Iure Belli Libri Tres (J.C. Rolfe (tra.), Oxford, 1933), p. 29a.

${ }^{116}$ Ibid, p. 15. 
${ }^{117}$ Ibid, pp. 22-24.

${ }^{118}$ Ibid.

${ }^{119}$ Ibid.

${ }^{120} \mathrm{Ibid}, \mathrm{p} .124$.

${ }^{121}$ Vattel.

${ }^{122}$ Ibid, Prelim. § 6; ibid, BK I, Chap. VIII, § 88.

${ }^{123}$ Ibid, Prelim. $\$ 22$.

${ }^{124} \mathrm{Ibid}$, BK I, Chap. XXIII, § 283.

${ }^{125}$ Ibid, § 281; also ibid, Chap. VIII, §§ 83-87; ibid, Chap. XIV, § 182; ibid, BK II, Chap. I, § 16; ibid, Chap. II, $\S 24$.

${ }^{126}$ Ibid, BK I, Chap. XXIII, §§ 282-283; ibid, BK III, Chap. III, §§ 26, 28.

${ }^{127} \mathrm{Ibid}$, BK I, Chap. XXIII, § 283.

${ }^{128}$ Ibid, Chap. XIX, § 233.

${ }^{129}$ Attorney General of Israel v Eichmann, 36 ILR 5 (Dist. Ct. 1961), pp. 28-29, affirmed by Eichmann, 36 ILR 277 (Sup. Ct. 1962).

${ }^{130}$ Vattel, BK I, Chap. XIX, § 232; ibid, Chap. XXIII, § 283.

${ }^{131}$ Ibid, Chap. VIII, § 94; ibid, BK II, Chap. I, § 2.

${ }^{132}$ Ibid, BK II, Chap. II, $\$ \S 21-24$.

${ }^{133}$ See also ibid, BK I, Chap. VII, § 81.

${ }^{134}$ French Maritime Ordinance of August 1861, Article 5; French Decree of 22 May 1803, Article 52; French Law for the Safety of Navigation and Maritime Commerce of 10 April 1825, Articles $1 \& 2$. Prior to the adoption by the Netherlands of a Penal Code on 3 March 1881, Article 4, the Netherlands applied the French Penal Code for the punishment of 'piracy'; Lunsford, pp. 36, 60; Portuguese Penal Code 16 September 1886, Article 162; Spanish Ordinance of the Royal Navy 1748, Article 4; Spanish Ordinance of 20 June 1801, Article 27, Ordinance of 12 August 1802.

${ }_{135}$ Articles 101, 105.

${ }^{136}$ An issue currently under preparation by the present author.

${ }^{137}$ See M. Garrod, "The Development of Protective Principle Jurisdiction over War Crimes and the Hollow Concept of Universality", International Criminal Law Review 12(2012).

${ }^{138}$ UN General Assembly Resolution, "The scope and application of the principle of universal jurisdiction", 16 December 2009, A/RES/64/117; Report of the Secretary-General prepared on the basis of comments and observations of Governments, "The scope and application of the principle of universal jurisdiction", 29 July 2010, UN Doc. A/65/181; Sixth Committee, "The scope and application of the principle of universal jurisdiction", Official Records of the UN General Assembly, sixty-seventh session, 6 December 2012, UN Doc. A/C.6/67/SR.12. 